www.gjit.eu

\title{
Ethical perception of Information Technologies at Computer Science Faculties
}

Blerta Prevalla

Suggested Citation:

Abstract

Keywords:

Blerta Prevalla, 
1. Introduction

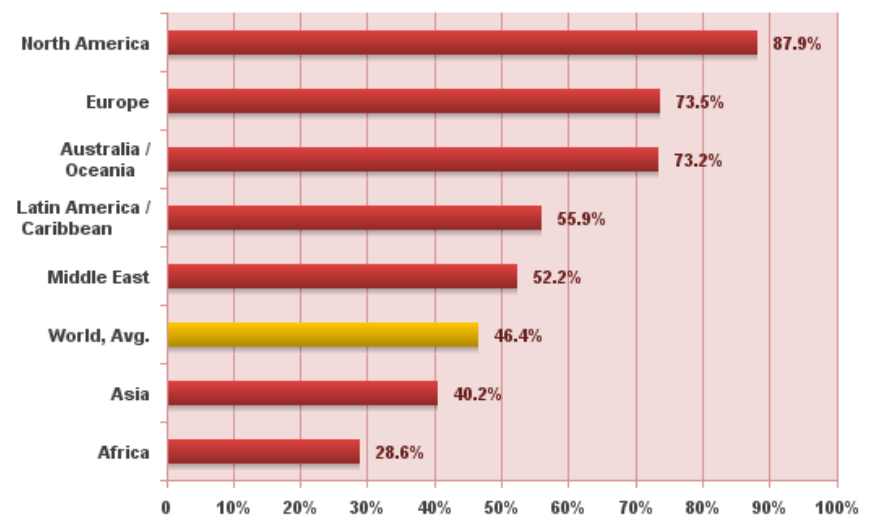

Figure 1. Internet world penetration rates-November $2015^{\mathrm{a}}$

Table 1. Internet usage and 2015 population in the European Union candidate countries ${ }^{b}$

\begin{tabular}{lccccc}
\hline $\begin{array}{l}\text { European union } \\
\text { candidates }\end{array}$ & $\begin{array}{c}\text { Population } \\
\text { (2015 Est.) }\end{array}$ & $\begin{array}{c}\text { Internet users } \\
\text { (30 November } \\
\text { 2015) }\end{array}$ & $\begin{array}{c}\text { Penetration } \\
\text { (\% Population) }\end{array}$ & $\begin{array}{c}\text { Users } \\
\text { (\% Table) }\end{array}$ & $\begin{array}{c}\text { Facebook } \\
\text { (15 November }\end{array}$ \\
& & & & 2015) \\
\hline
\end{tabular}


2. Case study: ethical perceptions of IT at computer science faculties

2.1. How do the students define ethics

2.2. How does students understand IT-ethics and what does it mean and has to do with?

2.3. How much do the students and the lecturers respect the ethical principles? 
2.4. What kinds of activities are preferred for improving ethical values

2.5. Adhering to ethical principles positively affect the learning process

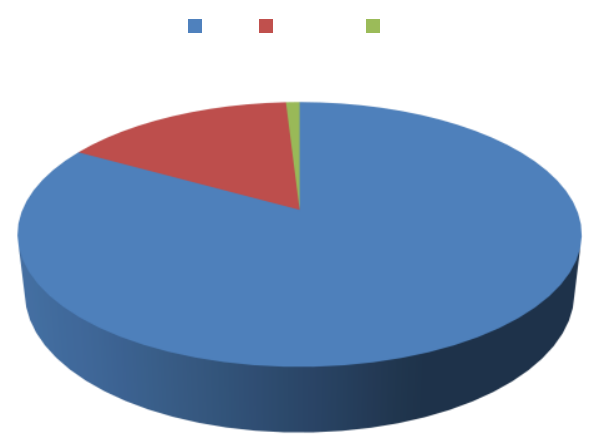

Figure 2. The impact of respecting the ethical principles in the teaching process

2.6. Respecting intellectual property rights, freedom of expression and anonymity 


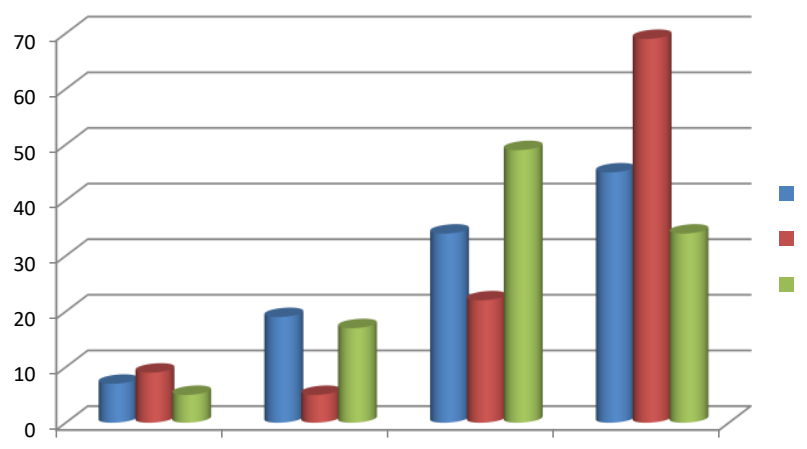

Figure 3. Respektimi i pronesise intelektuale, lirise se te shprehutit dhe anonimitetit

2.7. Njohurite rreth IT crime dhe mundesia e involvimit ne IT crime
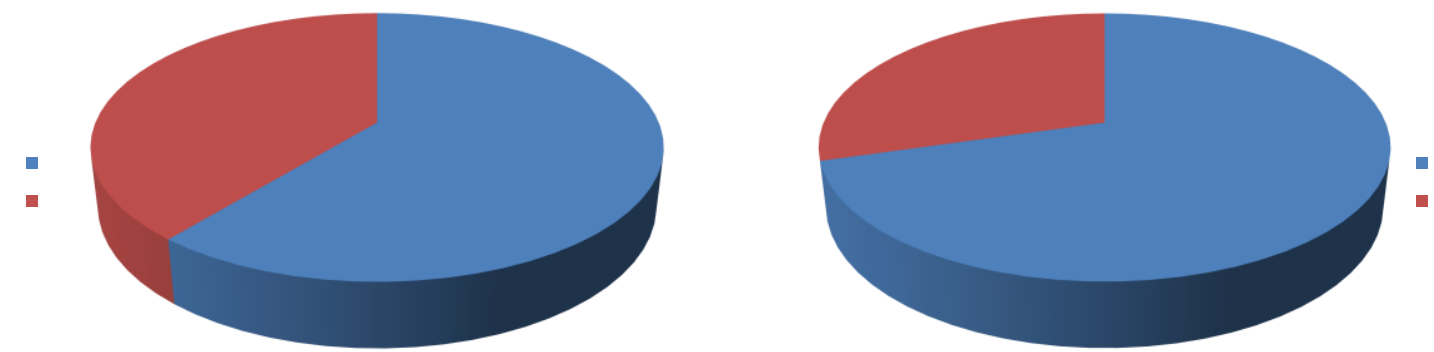

Figure 4. Njohurite rreth IT crime dhe mundesia e involvimit ne IT crime 


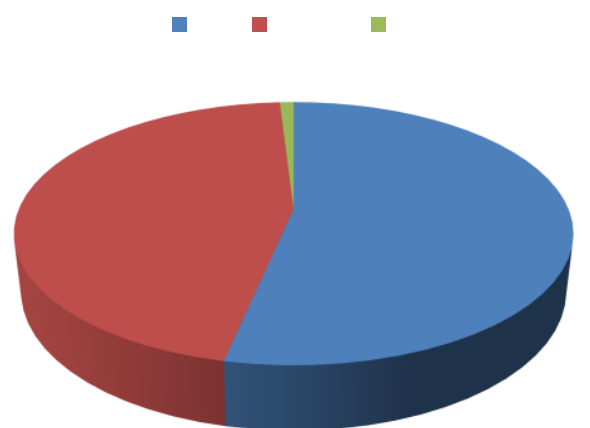

Figure 5. Nevoja per lende te etikes professionale ne Computer Science Faculties

3. Conclusion

References 
